\title{
COMPARISON OF COATED CARBIDE CUTTING TOOL INSERTS USED IN MACHINING OF CYLINDER LINERS MADE OF GREY CAST IRON
}

\author{
Čuban Jiří, Kovalčík Jaroslav \\ Department of Machining and Assembly, TU in Liberec
}

This article is aimed at the comparison of coated carbide cutting tool inserts used in machining of cylinder liners made of grey cast iron. The comparison has been realized through the tool life tests. The measurement has been carried out at three cutting speeds at constant cutting conditions. From the obtained values, the regression coefficients have been evaluated. Subsequently, extrapolation has been carried out by means of the regression line for the cutting speed in the range of $250-500 \mathrm{~m} / \mathrm{min}$, and for this the extended cutting speed range the interval reliability has been evaluated. In the experiments, it has been found, at the given conditions, it is not possible to recommend these cutting tool inserts for high speed machining.

Keywords: metal machining, carbides, coated cutting tool inserts, flank wear, tool life

\section{References:}

[1] HUMÁR, A. Slinuté karbidy a řezná keramika pro obrábění CCB spol. s.r.o. Brno 1995 ISBN:80-85825-10-4.

[2] VELECHOVSKÝ, J. Výběr povlakovaných slinutých karbidů $s$ aplikací v obrábění šedé litiny [Diplomová práce]. TU Liberec, 2005. Fakulta strojní.79s.

[3] KOVALČíK, J. Analiticko-syntetická studie na souboru řezných destiček z keramiky.[Diplomová práce]. TU Liberec, 2008. Fakulta strojní.104s.

[4] Anděl, J. Statistické metody. 4. vyd. MATFYZPRESS. Praha, 2007. ISBN 80-7378-003-8.

[5] KOHOUT, V. Kritické hodnoty a tabulky rozdělení - tabulka Studentovo rozdělení (podklad pro výuku předmětu PRAVDĚPODOBNOST A STATISTIKA). [online]. PIzeň: Západočeská univerzita v PIzni, fakulta pedagogická, katedra matematiky. Dostupné na:

http://www.kmt.zcu.cz/person/Kohout/info_soubory/letnisem/ruzne/tabst.htm.[červen 2009].

[6] MACHAČ, J., ŘASA, J., Př́ručka obrábění. 1.vydání,Sandvik CZ za pomoci nakladatelství Scientia, 1997. ISBN 91-97 22 99-4-6.

[7] SUMITOMO ELECTRIC HARDMETAL:Hardmetal turning tools, 2004.

[8] KOVALČíK, J. Comparison of cutting tool insert's made of oxide cutting ceramic machining of grey cast iron. Strojírenská technologie. roč. 14, březen 2009, č. 1. ISSN 1211-4162.

[9] KOVALČíK, J., ČUBAN, J. Comparison of Performance of Austrian made $\mathrm{Si}_{3} \mathrm{~N}_{4}$ - Nitride Ceramic Tools Used to Machine Grey Cast Iron Work-piece Materials. Modern Machinery (MM) Science Journal, October 2009. ISSN 1803-1269. 